\title{
Changing teachers' practice in the Creative Arts classroom: The case for educational technologies
}

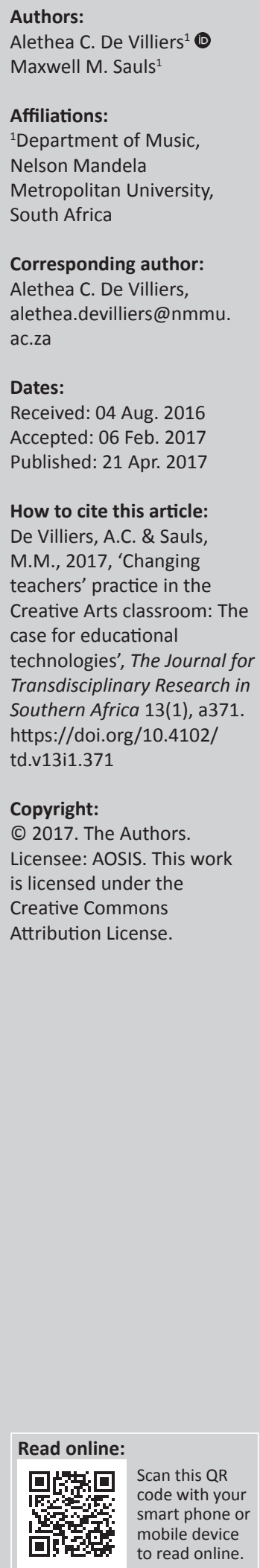

The study described in this essay explores the use of educational technology as a resource in the Creative Arts classroom. Many teachers are not qualified to teach Creative Arts. They then tend to rely on curriculum documents and textbooks to help guide their planning, teaching and assessment. Most of the teachers who participated in this case study were not specialists in any of the arts, and in the education district where this study took place, there was a lack of ongoing professional development for the Creative Arts. To enable the teachers from Grades $\mathrm{R}$ to 7 to mediate more meaningful classroom teaching and learning in the Creative Arts, the researchers introduced the teachers to technology as a means to facilitate learning and teaching.

This study follows a phenomenological approach to explore the use of educational technology in the teaching of dance, drama and music, which are three of the art forms in the Creative Arts. The researchers describe the teachers' perceptions and attitudes towards using technology in the classroom. Eight teachers participated in the study (seven female and one male), ranging in age from 22 to 41 years. There were three teachers from the Foundation Phase, three teachers from the Intermediate Phase and two teachers from the Senior Phase. Data were collected from (1) unstructured open-ended conversational interviews, (2) observations of the participants during contact time with learners and (3) audio-visual recordings of the teachers in the classroom.

Findings from the study showed that after the 10-month intervention of using educational technology in the classroom, there was divergence in the teachers' use of technology. The findings also suggest that classroom practice in dance, drama and music improved.

\section{Introduction}

Teachers need training and experience in order to mediate meaningful learning experiences to be effective in their profession (DoE 2012d:8-10; Shulman 1987). It is a global phenomenon that many teachers are not adequately trained or qualified to teach the non-specialist arts of dance, drama, music and the visual arts. Moreover, without the competences to mediate teaching and learning in the Creative Arts, research has shown that teachers may teach only those sections of the curriculum that they understand or neglect to teach certain art forms (Andrews 2006; Figuerido 2004; Nompula 2012; Vermeulen 2009). In this exploratory case study, the researchers sought to overcome the shortcomings of the teachers' lack of training in the Creative Arts through the introduction of educational technology.

\section{Educational technology}

A number of researchers concur that within their educational contexts learners are required to master more than the core curriculum in pursuit of future success in the employment industry (Blair 2012; Collis 2005:215-217; Scherer \& Cator 2011). These skills are embedded in the use of a variety of educational technologies. In first-world countries, transformation is taking place where the traditional three R's of Reading, Writing and Arithmetic are being merged with the four C's of Critical thinking, Creativity, Communication and Collaboration (Beschorner \& Hutchison 2013; Blair 2012; Darby \& Catterall 1994; Fogarty \& Stoehr 2008:23-42). Latham and Gross (2014:46-47) suggest that effective application of technological skills in the workplace requires acquiring the skills in a technology-infused learning environment when learners are still at school. Scheffler and Logan (1999:305) also recognise that because the world is becoming more technological and interconnected, policymakers, educators and the public acknowledge the importance of computer knowledge and skills in the daily lives of individuals as well as for national economic competitiveness. 
Children's out of school lives are characterised by the use of digital technologies. Owston (1997), Marsh (2005) as well as Twiner et al. (2010) remind us that teachers engage with learners whose lives have been immersed in media culture. Outside of school learners are assimilating the world through the filter of computing devices such as television, cellular phones, handheld gaming devices, electronic tablets and laptops (Chayko 2008:63-72; Imazeki 2014; Wientjes 2011:37). Beschorner and Hutchison (2013:20-22) describe how children navigate the electronic apparatuses in which they are faced with complex tasks such as analysing, synthesising and problem-solving. Popular cartoons aimed at learners aged 5-8 years include Dora the Explorer and Little Einsteins (Gordon-Biddle et al. 2013:279). These educationally based cartoons exploit the use of the computer model by presenting the narrative on a computer screen that mimics transitions, the movement of the mouse on the screen and computer tones (Beschorner \& Hutchison 2013:17-18).

Because of their familiarity with a number of media, learners tend to be keen to explore technology. Researchers report that in some educational contexts, learners are creating study groups on WhatsApp and navigating electronic tablets as textbooks (Imazeki 2014; Scherer \& Cator 2011). These learners also expect instant access to knowledge (Chayko2008:3-16; Cline 2014:63-70). With the world literally at the fingertips of the learners through the use of technology, education challenges teachers to re-envision the role of technology in the classroom (Klopfer et al. 2009:1-20; Marsh 2005).

Researchers have highlighted technology that has been used in education. These include (1) multimedia (Ware 2006); (2) interactive whiteboards (IWB) (Betcher \& Lee 2009; Twiner et al. 2010); (3) videos, video clips and movies (Berk 2009; White 2009); (4)YouTube (Duffy 2008; Jones \& Cuthrell 2011; White 2009); (5) iPads (Beschorner \& Hutchison 2013; Hutchison, Beschorner\& Schmidt-Crawford 2012; Kucirkova et al. 2014); (6) computers (Scheffler\& Logan 1999); (7) cellular phones (Imazeki 2014); and (8) digital technologies (Bruce \& Chiu 2015; Kirk \& Pitches 2013).

\section{Examples of the application of educational technology in the classroom}

Some of the technology affords learners opportunities for interactive engagement, such as multimedia and the interactive whiteboard. For example, Ware (2006) reports on a study where children converted written stories into multimedia presentations with images, music, movement and voice-over, after revisions and edits. Courts and Tucker (2012:122) state that multimedia can expand the boundaries of the classroom through the use of animation, text, audio, video, slideshows, podcasts, instant messaging and simulations. Twiner et al. (2010) and Cutrim-Schmid and Whyte (2012) describe classroom practice where the interactive whiteboard was used in whole class teaching where the learners actively participated in an interactive classroom. The specific example provided by Twiner et al.
(2010:219) describes how the learners worked with content: animations, static images and photographs were displayed, annotated and changes either discarded or saved. In the study described by Kirk and Pitches (2013), learners used digital technologies to reflect on creative practice and for creative forms of reflection. Other examples of multimedia such as videos, movies, YouTube and television are mainly used to provide a context and also to understand complex issues (White 2009).

iPads also allow for greater learner interaction and manipulation of media. Kucirkova et al. (2014) provide a description of the iPad Our Story application that can be used by children to create their personal multimodal stories. Whereas Hutchison et al. (2012) and Beschorner \& Hutchison (2013) viewed the iPad as a means of enhancing literacy lessons.

Interactive learner participation through the introduction of technology in the classroom leads to a paradigm shift in learning theory from behaviourist to social constructivist views of human cognition occurring in education (CutrimSchmid \& Whyte 2012; Daniels 2005; Vygotsky 1978; Leont'ev 1997). Researchers writing in the field of educational technology in the classroom agree that technology can lead to the teacher no longer being the centre of knowledge (Beauchamp \& Kennewell 2013; Betcher \& Lee 2009:47-62; Flewitt 2008; Hennessy, Ruthven \& Brindley 2005; Lin, Esmahi \& Poon 2005; Scheffler \& Logan 1999; Twiner et al. 2010; Ware 2006). Scheffler and Logan (1999:305) and Siegel (1995:455) explain that the approach to teaching and learning becomes more inquiry based where learners see themselves as knowledge makers and take responsibility for their own learning. Scheffler and Logan (1999:305-306) state that learning comes from learner inquiry, critical thinking and problem-solving based on information accessed from many sources. They also reveal that computers make it possible for the learners to engage in research, data analysis, knowledge application, communication and collaborative writing.

The phenomenon of educational technology in the classroom has also been recognised in South Africa. With the policy Operation Phakisa: ICT in Education (DoE 2015:17-19), there is an acknowledgement from the government that the integration of educational technology is inevitable. The policy points the way to the future when tablets and IWB will be available in the classroom. Within the context of e-education, this study focused on the integration of technology in the Creative Arts classroom.

Researchers inform us that technology is a powerful tool that can improve education in the arts if it is integrated systematically and implemented appropriately (Beauchamp \& Kennewell 2013; Pitler et al. 2007; Scheffler \& Logan 1999). Collis (2005) as well as Hooper and Rieber (1995:154-155) emphasise that the effective use of technology transforms instructional content from information to useful knowledge. Teachers and learners will then be able to access, analyse and apply information (Klopfer et al. 2009:1-20). Bruce and Chiu 
(2015) describe how learners use learning digital video for composing music. Gall and Breeze (2006:43) describe the use of technology in music classes over time, such as those that are still relevant today, namely audio recordings, surround sound encoder with multitrack recording, music software for computers and music genres that developed from technology.

Curriculum policy statements in South Africa recognise that education encompasses the holistic development of learners (DoE 2012b:8-9, 2012c:8-10, 2012d:8-10). The National Curriculum Statement (NCS) refers to development in all areas, including that of technology (DoE 2012a, 2012b:8). The skills learnt through arts education are interdisciplinary, integrated and project based in nature. These skills include the following:

- using language, text and symbols interactively

- using media tools interactively

- processing data and reporting results

- creating original works as a means of personal and group expression

- synthesising experiences coherently

- communicating ideas effectively to multiple audiences using a variety of media formats (DoE 2012a, 2012b, 2012c, 2012d).

From these skills, it is evident that the arts curricula are complex and integrate higher-order thinking skills, technology, multimedia and the literacies of the present century (DoE 2012d). In addition, arts curricula worldwide, including in South Africa, are often thematic and have many other distinguishing features, such as being multidisciplinary, project based and research driven (Burton, Horowitz and Abeles 2000; Darby \& Catterall 1994; Kassing \& Jay 2003; McDonald \& Fisher 2006). Furthermore, the arts disciplines extend to incorporate the wider community which refers to building relationships between the local, provincial, national and global communities through the use of technology (Beauchamp \& Kennwell 2013:201,179; Blair 2012:10-11; Hilmes 2014:232-478; Owston 1997; White 2009).

While engaging with the arts curricula, learners construct knowledge through research, personal experience and associations made with prior knowledge (Franklin 2011: 201; Inhelder \& Piaget 1958; Vygotsky 1978; Leont'ev 1997; Walls 2000:16-19; Webster 2006). Skills are acquired through research and application in projects (Haycock 1991; Klopfer et al. 2009:6).

Before the research study began, one of the researchers presented a short professional development workshop in the Creative Arts to the teachers at the school. He then proceeded to explain and demonstrate how the technology could be used to enhance the teaching and learning in the classroom in dance, drama and music, which is the focus of this study. The following is a description of the technologies to which the teachers were introduced.

In dance, the teachers were introduced to (1) the video camera on smart phones to record learners' performances;
(2) dance-inspired fitness videos such as Hip Hop Abs and Zumba for warm-up routines; (3) how to create a YouTube channel and upload learner performances; (4) how to utilise video games of a kinematic nature such as Dance Dance Revolution, Just Dance Wii or Dance Central. Two or more learners can use the controllers while the other learners stand behind them and mimic the movements. The class can be divided into groups that compete against each other; (5) dance-related software such as Great dance debate and Stimulus that can be downloaded from the internet for free. These programmes have been developed to allow learners to think abstractly in a controlled environment within the parameters of the curriculum; (6) having the learners use the internet for research art forms and present the project as a PowerPoint presentation and a practical demonstration.

In drama, the teacher can (1) use a timer to ensure good time management; (2) use a megaphone to practise voice projection, speaking in a range of dynamic levels; (3)utilise interactive story books that allow for learner participation. In music, the teacher can use (1) a MIDI keyboard with music software to compose simple phrases; (2) an interactive whiteboard to teach music notation; (3) a metronome to teach tempo in music. For dance, drama and music, the internet, DVDs, movies and YouTube can be sources for content and context. A CD player or MP3 player can be used to play music in dance, drama and music. In dance and drama, the learners can create digital diaries. For school concerts, learners can use the microphone and also experiment with sound and lighting. Table 1 provides a summary of the technology that was accessible to the participating teachers, including technology that they intended to develop.

\section{Research methodology}

The research followed a phenomenological approach, by interpreting the meaning the intervention had for the teachers who participated in the study (Creswell 2013: 24-25). From an epistemological viewpoint, phenomenology is based in a paradigm of personal knowledge and subjectivity.

\begin{tabular}{|c|c|c|}
\hline Dance & Drama & Music \\
\hline \multicolumn{3}{|c|}{ Educational technology accessible to the teachers in the study } \\
\hline Television/dance shows & Television & Television/cartoons \\
\hline DVD player and DVD & DVD player and DVD & DVD player and DVD \\
\hline $\begin{array}{l}\text { CD player/MP3 player } \\
\text { and CD }\end{array}$ & $\begin{array}{l}\text { CD player/MP3 player } \\
\text { and CD }\end{array}$ & $\begin{array}{l}\text { CD player/MP3 player } \\
\text { and CD }\end{array}$ \\
\hline Tablet/laptop/PC & Tablet/laptop/PC & Tablet/laptop/PC \\
\hline Overhead projector (OHP) & Overhead projector (OHP) & Overhead projector (OHP) \\
\hline Video recorder & Video recorder & MIDI keyboard \\
\hline Cellular phone & Cellular phone & Interactive whiteboard \\
\hline Webcam & Toy microphone & Video recorder \\
\hline Interactive games & Megaphone & $\begin{array}{l}\text { Portable rechargeable } \\
\text { speakers }\end{array}$ \\
\hline Dance software & Interactive books and CD & Metronome \\
\hline \multicolumn{3}{|c|}{ Technologies that teachers and learners intended to develop } \\
\hline Digital dance diary & Digital drama diary & Digital music diary \\
\hline YouTube channel & & \\
\hline
\end{tabular}

Source: Sauls (2016) 
Perspectives and interpretations led to an understanding of the motivations and actions of the teachers over the 10 months of this study as they used technology in the dance, drama and music classes (Johnson \& Christensen 2014:49).

Data were collected from (1) unstructured open-ended conversational interviews (Merriam \& Tisdell 2015:137-161); (2) observations of the participating teachers during contact time with learners (Fetterman 1998:34-35); (3) field notes taken during the observations (Kawulich 2005); and (4) audio-visual recordings of the teachers in their classrooms (Merriam 2002:13).

\section{The sample}

Purposive sampling was used, as all the participating educators teach Life Skills or Creative Arts ${ }^{1}$ at one school, where one of the researchers is also a teacher (Boeije 2010:35). Eight teachers participated in the study (seven females and one male), ranging in age from 22 to 41 years. Three teachers were from the Foundation Phase (FP), Grades $\mathrm{R}$ to 3; three from the Intermediate Phase (IP), Grades 4 to 6; and two teachers who both teach Grade 7, were from the Senior Phase (SP).

\section{Data analysis}

Qualitative data were collected from the interviews, observational field notes and audio-visual recordings. The researchers identified emergent themes or topics that are discussed in the 'Findings and discussion' section.

\section{Ethical considerations}

The ethics clearance number for this study is H/14/ART/ MUS-001.

\section{Findings and discussion}

The themes that emerged from this research are discussed under subheadings in the sections that follow.

\section{The school curricula in the case study}

The South African Schools Act of 1996 (RSA 1996) recognises two categories of schools: state-controlled and independent schools. The school in this study is owned and operated by a church. It is an independent primary school in a previously disadvantaged community in Port Elizabeth.

Prior to 2013, the school followed an American-based curriculum. The then South African Department of Education, now Department of Basic Education, began its rollout of the revised curriculum, from 2013 onwards.

\footnotetext{
1.In 1998, a broadlybanded, outcomes-based curriculum was introduced in schools in South Africa. One of these broadlybanded learning areas was Arts and Culture, which inter curriculum was published in 2002. In 2010, the curriculum was revised for a second time. Arts and Culture was renamed as Creative Arts. In Grades R to 6, Creative Arts form part of Life Skills and is organized into two streams, Visual Arts and the performing arts consisting of dance, drama and music. From Grades 7 to 9 , Creative Arts is a separate subject, with policy stipulating that schools choose two art forms (from visual arts, dance, drama and music) for specialization.
}

At this time, the school management decided to opt for the departmental curriculum for the IP. After consulting the FP teachers, the school management decided to maintain the status quo of the FP. The consequence of this decision is that when learners enter Grade 4, they do not have any experiences in either dance or drama and have limited experience in music.

This situation was confirmed by the Grade 4 teacher, Mary²:

I do not know that much about dance, music and drama but when the learners enter grade four they have no clue what I am talking about. They enter a new phase, with new subjects. They do not do the same work as they did in grade three. I am not sure what they learnt for music but it did not help me at the start of the year.

An analysis of the curriculum followed by the FP showed that it was not comprehensive and only focused on two elements of music, namely the learning about music instruments and their sound (tone colour), and the emotion that the music evokes (mood). Additionally, the time allocated for music in the FP was 30 minutes on each Friday of the fourth term, and not the entire year, which is considerably shorter than the government guideline of 2 hours per week for four art forms over a year (DoE 2012b:6). The children in the FP therefore followed a limited music curriculum.

Although Grades 4 to 7 followed the government syllabus, time allocation for the Creative Arts in the IP was up to the discretion of the teacher. According to departmental guidelines, the Creative Arts should be allocated one and a half hours per week on the timetable (DoE 2012c:10).

Primrose confirmed this with the statement regarding her own practice:

Life Skills is very demanding and working out lesson plans is not easy. I don't understand all the different art things that the department expects me to teach. Even though I teach Life Skills. I spend more time teaching the other components and give the learners any activity to have marks to capture on the system.

In contrast, in Grade 7, the time allocated to the art forms Dance and Music, which were the specialisations chosen by the school given the expertise of the teachers, was an hour a week. This is in accordance with the recommended time allocation as stated in the curriculum policy statement (DoE 2012d:7).

\section{Training in dance, drama and music: The responses of the participating teachers}

According to the curriculum statement document, teachers should be (1) capable of teaching the art forms and (2) the school management and the school governing body should ensure that teachers receive intensive training in one or

2.Not her real name. Throughout, the researchers use pseudonyms to protect the identity of the teachers who participated in this study. Ethics clearance was obtained
from the Ethics Committee of the Nelson Mandela Metropolitan University to conduct this study. The ethics clearance number is H/14/ART/MUS-001. 
more art forms (DoE 2012d:9). However, six of the teachers felt that they were not particularly well-qualified to teach the Creative Arts. Teachers in the FP lacked a general understanding of the basic underpinnings of music education. As a consequence, they relied on worksheets sourced from the internet to supplement the content in workbooks. Their teaching style could be described as narrative teaching whereby learners would listen to the teacher. This teaching style did not foster creativity or enable active learner participation in the music class. The following are some of their responses. Lucy, who is the youngest teacher, and an enthusiastic Grade 2 teacher, had this to say:

'In the Bachelor of Education course we had an arts module. However, we were only introduced to the elements of the arts forms. We did not do any content and methodology. I therefore did not feel prepared to teach the curriculum.'

Naomi, a Grade 3 teacher, shared the following:

'I usually start the year by letting the learners sing familiar songs as this is the easiest way to begin. I am not so confident in the way I teach music. Although I do sing in the worship team at my church, teaching is different from pure singing'.

Two participants had completed one-year courses offered through a local early childhood development institution located within the metropolis. Two different participants have national diplomas in Educare training. Professional development in the performing arts was not included in any of these qualifications. The FP and IP teachers in this study needed professional development in the Creative Arts to prepare them for classroom practice. Even younger staff members who had qualified since the inception of the new curriculum in 1998 were not adequately qualified in the Creative Arts.

During the pre-interview stage, Matthew, a SP teacher, stated that:

I had been dancing for approximately a year already before the implementation of CAPS. The Grade 7's are taught concepts of dance and not actual dance routines. Although when I received some training while studying, they focussed on actual dance routines and never taught us about the concepts as it is stated in the textbook.'

Monica, a Grade 7 teacher, who qualified 20 years ago and is the oldest teacher in the group, had a different experience in pre-service training. She said:

When I was at the teachers college, one could major in either music or visual art. Our lecturer concentrated on music theory, so we did not do any of this... erm... stuff we find in CAPS'.

She also shared:

'Less than ten years ago I participated in a three arts initiative programme that focused on practical implementation of dance, drama and music. The course consisted of assignments, demonstrations and reflections on practically carrying out what we were taught in the classroom.'
Matthew has a BMus (Ed) degree and was the most qualified in a specific art from. During his BMus (Ed) degree, he enrolled for teaching modules, namely dance in the classroom and drama in the classroom. So, although he majored in music, he has knowledge and some practical experience of dance and drama. Matthew concluded the description of his training by saying:

'The instruction I received from the lecturers only assisted to a certain extent. The (curriculum content) objectives of the (Creative) Arts do not change but only the wording differs from curriculum to curriculum.'

Moreover, Matthew and Monica, the two Grade 7 teachers, have been involved in various arts programmes in the school such as, arts and crafts, recorder lessons, coordinating the school plays and concerts, and training learners for the various items. Both teachers attended ballroom and Latin American dance classes.

Due to Matthew's expertise in music and broad knowledge of dance and drama, the educators of the IP sought his assistance in preparing their lessons. He was always eager to assist as this was his area of expertise, more specifically, music education. Primrose, an IP teacher, goes on to explain how Matthew assisted her:

'Matthew would come to my class after school and teach me how to draw the music notes and how the stave works. He tried different ways of doing it and I chose the one that I understood the best. He would bring his instruments for me to use. He would help me to come up with ideas for assessments and provided rubrics for me to use. He would tell me what he expects the Grade 6's to be taught so that it makes his job easier the following year'.

Mary an IP teacher preferred to work independently. This was confirmed by Primrose, Monica and Matthew. Monica has always gravitated towards the Arts and thus her initial form of instruction was appropriate from the onset. Monica stated:

'Growing up being in drama performances and singing in the choir has helped me to be creative in class. I later started playing the recorder and the guitar. This helped me especially when I taught music because the guitar is a versatile instrument and can be taken anywhere. I even used it to teach the alphabet in Afrikaans (teaching the children an Afrikaans alphabet song).'

\section{The use of technology in Creative Arts (dance, drama and music)}

In this study, the technological devices that were used most frequently in the classroom were the smartphone, speakers and laptop. Participants most often used their smartphones as a music player because of one of the functions of the device itself. The speaker of the smartphone is not powerful enough; therefore, an external sound device was attached to the smartphone. Lucy, a frequent user of the smartphone said:

'I have a lot of music on my phone and this helped me to play music that the learners know but I also introduce other songs as well.' 
The laptop was the second most popular device used in the classroom as a tool for teaching and learning in dance, drama and music. Participating teachers used laptops to play videos clips to learners. These videos were based on the content of the Creative Arts curriculum. Lucy who teaches the youngest of the all the learners concurred with this statement:

'Learners did not realise that I was actually teaching them. I just made use of the laptop to do the teaching for me. Learners enjoy cartoons and they really enjoyed seeing characters like Donald Duck on the screen. They did not realise that the music was playing in the background.'

The teachers who participated in the study were of the opinion that technology improved their classroom practice. Technology enabled them to expand the educational resources to assess higher-order cognitive skills and not only comprehension. Naomi, one of the other FP teachers, stated the following:

'I found better worksheets from the internet. I am not saying that the worksheets we use are bad but the ones on the internet had more variety and the layout was better. I could use ideas from it for the next lesson.'

The teachers played sound clips, had learners watch a section of a movie and used dance exercise videos to teach warm-up exercises through dance. The teachers also made use of YouTube videos and CDs to play music. Rachel an FP teacher shared the following:

'I feel very confident in using technology in the classroom. I made use of my cellular phone and connected my shox to it. It helped me to understand what I was expected to do during the observation.'

The teachers of the IP chose to begin with warm-up exercises for dance and drama with Zumba. ${ }^{3}$ Mary said:

'The warm-up exercises caused such an excitement that I found it difficult to get the learners quiet after the exercise.'

Mary, an IP teacher, was not as keen as the other participants to use technology in her classroom. She stated:

'It's nice to use videos and other things to help with teaching but it takes a lot of time to prepare lessons and find things to make it interesting. I teach Natural Sciences and Technology also and don't always have a lot of time to prepare lessons using laptops.

Further evidence that the technology was mainly used by the teachers is evident in both Matthew and Monica's testimony. Both of them made use of video technology to record their learners' dance performances. Monica had this to report:

'I recorded the learners' dance performances and viewed this at home. I then assessed them, which felt fairer once I had the opportunity to view performances more than once.'

Due to the time allocations for dance, drama and music, it was essential for performances to be recorded and assessed later. The timetables of the teachers in the study showed that

3.Zumba is a dance fitness programme.
Creative Arts was timetabled closer to the end of the day. Fatigue sets in as the day progresses. Teachers would find it difficult to assess fairly if they did not concentrate on performances. Videotaping the performances reduces the stress placed on the teacher. Additionally, the use of technology limited bias because it allows for viewing performances multiple times. This enabled the teacher to make fair comparisons of the performances of groups and individuals. The digital dance diaries were not used for reflection on creative activities nor were they used for creative reflection.

YouTube and CDs made different styles of music more easily accessible without attending live concerts. This is reflected by statements made by two of the teachers.

Gretchen (IP) stated:

'I don't know a lot about classical music but the videos I found helped me to introduce learners to the different instruments and sounds they make.'

Naomi (FP) commented on how she had used the internet to prepare for her drama class. she said:

'Googling plays helped me to come up with ideas for the concert. I chose a play about animals. Videos helped me to see how the animals move and the sounds they make.'

The internet search of characters helped the teacher to understand the mannerisms of a character. Learners are not always acquainted with the attributes of a character, nor are teachers. By viewing other drama performances, the teacher became the more knowledgeable other, instructing learners how to act in their roles.

As is evident in the findings, across the three phases, teachers mainly used technology for content as a teaching resource and to explore topics. Consequently, the use of technology in the Creative Arts lessons was almost exclusively teachercentred as the teachers were the main users of technology in the classroom. Technology assisted them in teaching a subject, Creative Arts, in which they were not adequately trained. Notwithstanding this fact, although the learners were not active users of technology, they were actively engaged in completing worksheets and in performing music, dance and drama.

The exception to this trend in the use of technology was the utilisation of computers by the Grades 4 to 7 learners. The learners' use of the computer laboratory resulted in more learner interactions with technology. Through the use of computers, the roles of the teacher and learner shifted; teachers became the facilitators and the learners became more engaged with their own learning. Learners explored the internet, made use of virtual instruments, discovered answers to questions and sourced videos on YouTube of relevant dance, drama and performances. Primrose stated:

'I don't understand everything about computers but I am happy that I and the computer teacher worked together on this. 
He helped the learners with the more complex procedures that I do not understand. In this way we cover both the computer syllabus and Creative Arts syllabus at the same time.'

She added:

Computers help to allow learners to be creative and use imagination. The internet helped learners to find pictures and videos on drama performances. They copied these and added their own flavour to the performances.'

The underlying skills that learners were developing were how to use the computer mouse, typing skills, navigational skills and critical selection of content relevant to the dance, drama and music components of the Creative Arts curriculum. These skills were all embedded in exercises and demonstrate the cross-disciplinary nature of the arts.

Grade 7 learners were the most interactive in their use of technology and also made use of virtual instruments (MIDI keyboard) and composed using music software. These learners were also taught by teachers who were the most qualified and competent in the two specialisations (dance and music) of Creative Arts chosen by the school.

Furthermore, learners from Grades 4 to 7 used microphones, lighting and sound effects for their Christmas concert.

Consensus was reached among the participating teachers that they had to explain the expectations of each lesson. Learners would be responsible for safeguarding the technology and taking ownership of their own learning. Gretchen an IP teacher was particular about this and stated:

'Younger learners can be wild and play around with expensive things that might just break. I don't have money to replace the equipment and the school itself does not get funding for this. I need to train my children now because when we do use other forms of technology they need to respect that.'

\section{Professional development as ongoing and classroom based}

The participating teachers took the time to sit down and plan the lessons according to the abilities of the respective learners they taught. Participants were autonomous in their planning and catered to the needs of their learners while using the classroom to create a conducive learning environment. They also found that through using technology they became more confident to teach the Creative Arts, specifically dance, drama and music.

During the time that the study took place, the district office of the Department of Education held professional development workshops in the Creative Arts during the third term. This was a 12-week course to develop the teachers' knowledge, skills and competences to teach the Creative Arts. The workshops were presented twice a week on Friday afternoons, after school and on Saturday mornings. Attendance at this workshop was voluntary. Of the teachers who participated in this study, only Monica and Matthew attended these as the workshops were focused exclusively on Grade 7. The district education department did not provide professional development opportunities in the Creative Arts to the FP and IP teachers and those teaching Grades 8 and 9. This meant that the teachers participating in the study remained dependent on their colleagues and on the available education technology to teach the Creative Arts.

\section{Improved classroom engagement and motivation}

The use of technology in the classroom enhanced both the learners' engagement and motivation. Learners who were lethargic and not interested in the beginning of the study had changed at its conclusion. This motivation and engagement can be ascribed to the content that was learnt or new skills gained by the incorporation of technology.

Learners from the FP classes who were usually absent on a Friday came to school. This was confirmed by checking the attendance register kept by the participating teachers.

An increase in learner involvement in learning activities was observed. Once technology was introduced and became part of classroom practice in the Creative Arts, the learners desired a similar approach across the curriculum. It is this observation that has led the researchers to conclude that technology as a tool can be used effectively in the classroom to facilitate teaching and learning.

Due to an increase in learner engagement, fewer behavioural problems were observed. Learners who misbehaved were excluded from activities. Learners did not want to be excluded from the activities and so they displayed good behaviour.

\section{Recommendations from participating teachers}

At the end of the study, some of the participating teachers made recommendations that relate to training and also to resources. Three of the participating teachers suggested that the school should purchase resources such as laptops for the teachers' use and tablets for teaching. One of the respondents emphasised the need for more training. He stated:

The teachers need more training in Creative Arts. I help where I can. Teachers need to understand the basic concepts of all the art forms. At present, they don't.'

\section{Emerging patterns in the technology-infused classroom}

The participating teachers had been introduced to different technologies at the beginning of the study. As the findings reveal, they used most of the technology that was available to them with the exception of the digital diaries for drama and music, the metronome, the webcam and the interactive whiteboard. Cellular phones were used exclusively by the teachers and not the learners as a result of school rules pertaining to cellular phone use by learners during 
TABLE 2: A summary of the teachers' use of technology in the study.

\begin{tabular}{|c|c|c|}
\hline Grade & Technology used in the lesson & Classroom activities \\
\hline Grade R & $\begin{array}{l}\text { CDs, smartphone, speakers, } \\
\text { laptop, } \mathrm{Hi}-\mathrm{Fi}\end{array}$ & $\begin{array}{l}\text { Learners sang along to nursery } \\
\text { rhymes; worksheets from the } \\
\text { internet }\end{array}$ \\
\hline 1 & $\begin{array}{l}\text { CDs shox, smartphone, } \\
\text { speakers, laptop, YouTube videos }\end{array}$ & $\begin{array}{l}\text { Learners identified which } \\
\text { instrument made the sound (tone } \\
\text { colour); learners completed } \\
\text { worksheets from the internet }\end{array}$ \\
\hline 2 & $\begin{array}{l}\text { Video clips, smartphone, } \\
\text { speakers, laptop }\end{array}$ & $\begin{array}{l}\text { Learners painted a picture based } \\
\text { on the story; learners completed } \\
\text { worksheets from the internet }\end{array}$ \\
\hline 3 & $\begin{array}{l}\text { Smartphone, speakers, laptop, } \\
\text { worksheets sourced from the } \\
\text { internet }\end{array}$ & $\begin{array}{l}\text { Learners wrote a short description } \\
\text { of a character on the page }\end{array}$ \\
\hline 4 & $\mathrm{CDs}$, videos, video recorder, $\mathrm{Hi}-\mathrm{Fi}$ & $\begin{array}{l}\text { Learners performed a drama piece } \\
\text { focusing on a societal issue }\end{array}$ \\
\hline 5 & $\begin{array}{l}\text { Computers, videos, video } \\
\text { recorder, CDs, MP3s, laptops }\end{array}$ & $\begin{array}{l}\text { Learners performed Zumba } \\
\text { warm-up exercises for dance and } \\
\text { drama; learners wrote a reflective } \\
\text { journal entry on a drama } \\
\text { performance }\end{array}$ \\
\hline 6 & $\begin{array}{l}\text { CDs, videos, video recorder, } \\
\text { MP3s, laptops, kitchen timer }\end{array}$ & $\begin{array}{l}\text { Learners performed Zumba } \\
\text { warm-up exercises for dance and } \\
\text { drama; learners danced }\end{array}$ \\
\hline 7 & $\begin{array}{l}\text { OHP, videos, video recorder, dance } \\
\text { video diary, CDs, MP3s, laptops, } \\
\text { microphones, lighting and sound } \\
\text { effects, MIDI keyboard }\end{array}$ & $\begin{array}{l}\text { Learners researched dance and } \\
\text { music on the internet } \\
\text { Learners listened to music and } \\
\text { composed music }\end{array}$ \\
\hline
\end{tabular}

Source: Sauls 2016

school hours. Table 2 presents a summary of the use of technology in the Creative Arts.

\section{Conclusion}

In this study, the researchers introduced teachers to technology to facilitate teaching and learning in the Creative Arts classroom. The introduction of technology in the Creative Arts classroom served a dual purpose. Firstly, the researchers recognised that learners interact with technology daily outside of the classroom. Introducing technology into the classroom was viewed as a means of formalising the development of high-order cognitive skills such as problem-solving, decision-making, creative thought and technology skills in the Creative Arts.

Secondly, due to the teachers having a limited understanding of the Creative Arts, one of the researchers provided support and guidance with respect to content and classroom practice to the teachers participating in the study. He introduced them to educational technology to enhance their classroom practice in the Creative Arts. After engaging with technology, the findings as discussed in this article reveal that there was a divergence in the use of technology in the Creative Arts. This divergence was apparent across the different art forms, among teachers and even within individual teacher's use of technology.

The incorporation of technology alone did not ensure a change in classroom practice. Technology set in motion a change in how the teachers and learners engaged with the Creative Arts. A shift in the role from 'teacher' to 'facilitator' became more evident, especially in the IP and SP.

This study highlighted the fact that teachers needed more in-depth professional development in the art disciplines. The researchers therefore recommend that professional development workshops should be ongoing to develop competences in the Creative Arts. The researchers believe that increased competences to mediate learning and teaching in the Creative Arts could lead to more innovation in the use of technology in the classroom.

The researchers acknowledge that the current study is limited in that it focused almost exclusively on the teachers. A future study could focus on a more learner-centred approach in the use of technology. This could include learners interacting with the technology such as using multimedia to create their own digital diaries for reflective practice.

Finally, the study emphasised an area in education that could become increasingly researched and discussed in years to come. Education is moving in a direction where technology will be the minimum standard and requirement in classrooms. The researchers motivate that in the absence of ongoing professional development workshops, nonspecialist teachers in the arts should be encouraged to explore how technology can improve their practice.

\section{Acknowledgements}

This article is based on a study which was part of a Master's degree.

\section{Competing interests}

The authors declare that they have no financial or personal relationships which may have inappropriately influenced them in writing this article.

\section{References}

Andrews, B.W., 2006, 'Re-assessing the effectiveness of an arts partnership in teacher education', International Review of Education 52(5), 443-459. https://doi.org/ 10.1007/s11159-006-9003-2

Berk, R.A., 2009, 'Multimedia teaching with video clips: TV, movies, YouTube, and $\mathrm{mtvU}$ in the college classroom', International Journal of Technology in Teaching and Learning 591, 1-21.

Beauchamp, G. \& Kennewell, S., 2013, 'Transition in pedagogical orchestration using the interactive whiteboard', Education and Information Technologies 18, 179-191. https://doi.org/10.1007/s11159-006-9003-2

Beschorner, B. \& Hutchison, A., 2013, 'iPads as a literacy teaching tool in early childhood', International Journal of Education in Mathematics, Science and Technology 1(1), 16-24.

Betcher, C. \& Lee, M., 2009, The interactive whiteboard revolution: Teaching with IWB's, Acer Press, Camberwell, Australia.

Blair, N., 2012, 'Technology integration for the new 21st century learner', Principa 91(3), 8-13.

Boeije, H.R., 2010, Analysis in qualitative research, Sage, Thousand Oaks, CA.

Bruce, D.L. \& Chiu, M.M., 2015, 'Composing with new technology: Teacher reflections on learning digital video', Journal of Teacher Education 66(3), 272-289. https:// doi.org/10.1177/0022487115574291

Burton, J.M., Horowitz, R. \& Abeles, H., 2000, 'Learning in and through the arts: The question of transfer', Studies in Art Education 41(3), 228-257. https://doi. org/10.2307/1320379

Chayko, M., 2008, Portable communities: The social dynamics of online and mobile connectedness, SUNY Press, Albany, NY.

Cline, H.F., 2014, Information and communication technology and socia transformation: Asocial and historical perspective, Routledge, New York.

Collis, B., 2005, 'E-learning and the transformation of education for a knowledge economy', in M. Castells \& G. Cardoso (eds.), The knowledge society: From knowledge to policy, pp. 215-224, The John Hopkins University Center for Transatlantic Relations, Washington, DC.

Courts, B. \& Tucker, J., 2012, 'Using technology to create a dynamic classroom experience', Journal of college Teaching \& Learning 9(2), 121-127. https://doi. org/10.19030/tlc.v9i2.6907 
Creswell, J.W., 2013, Qualitative inquiry and research design: Choosing among five approaches, 3rd edn., Sage, Thousand Oaks, CA.

Cutrim-Schmid, E. \& Whyte, S., 2012, 'Interactive whiteboards in state school settings: Teacher responses to socio-constructivist hegemonies', Language Learning and Technology 16(2), 65-86.

Daniels, H. (ed.), 2005 An introduction to Vygotsky, 2nd edn., Routledge, East Sussex.

Darby, J.T. \& Catterall, J.S., 1994, 'The fourth R: The arts and learning', Teachers College Record 96(2), 299-328.

Department of Basic Education, 2015, Action plan to 2019: Towards the realisation of schooling 2030, viewed 15 August 2015, from http://www.education.gov.za/

Department of Education, 2012a, National curriculum statement: Curriculum and assessment policy statement, Government Printers, Pretoria.

Department of Education, 2012b, Curriculum and policy statement: Life skills Foundation phase, Government Printers, Pretoria.

Department of Education, 2012c, Curriculum and policy statement: Life skills Grades 4-6, Government Printers, Pretoria.

Department of Education, 2012d, Curriculum and policy statement: Creative arts: Grades 7-9, Government Printers, Pretoria.

Duffy, P., 2008, 'Engaging the YouTube Google-eyed generation: Strategies for using web 2.0 in teaching and learning', The Electronic Journal of E-Learning 6(2), 119-130.

Fetterman, D.M., 1998, Ethnography step by step, 2nd edn., Sage, Thousand Oaks, CA

Figuerido, S.L.F., 2004, 'Teaching music in the preparation of generalist teachers: A Brazilian experience', Bulletin of the Council of Research in Music Education $161 / 162,73-81$

Flewitt, R., 2008, 'Multimodal literacies', In J. Marsh, \& E. Hallet, (eds.), Desirable literacies: Approaches tolanguage and literacy in the early years, pp. 122-139, Sage, London.

Fogarty, R.J. \& Stoehr, J., 2008, Integrating curricula with multiple intelligences: Terms, themes, and threads, Corwin Press, Thousand Oaks, CA.

Franklin, T.J., 2011, 'The mobile school: Digital communities created by mobile learners', in G. Wan \& D.M. Gut (eds.), Bringing schools into the 21st century, pp. 187-203, Springer, Dordrecht.

Gall, M. \& Breeze, N., 2006, 'The times they are a-changing: The subculture of music and ICT in the classroom', Technology, Pedagogy and Education 16(1), 41-56. https://doi.org/10.1080/14759390601168015

Gordon-Biddle, K.A., Garcia-Nevarez, A., Roundtree-Henderson, W.J. \& Valero-Kerrick A., 2013, Early childhood education: Becoming a professional, Sage, Thousand Oaks, CA.

Haycock, C.A., 1991, 'Resourced-based learning: A shift in the roles of teacher, learner', NASSP Bulletin 75(535), 15-22. https://doi.org/10.1177/01926365910 7553505

Hennessy, S., Ruthven, K. \& Brindley, S., 2005, 'Teacher perspectives on integrating ICT into subject teaching: Commitment, constraints, caution, and change', Journa of Curriculum Studies 37(2), 155-192. https://doi.org/10.1080/00220270320 00276961

Hilmes, M., 2014, Only connect: A cultural history of broadcasting in the United States, 4th edn., Wadsworth Cengage Learning, Boston, MA.

Hooper, S. \& Rieber, L.P., 1995, 'Teaching with technology', in A.C. Ornstein, (ed.), Teaching: Theory into practice, pp. 154-170, Allyn \& Bacon, Needham Heights, MA.

Hutchison, A., Beschorner, B. \& Schmidt-Crawford, D., 2012, 'Exploring the use of the iPad for literacy learning', The Reading Teacher 66, 15-23. https://doi. org/10.1002/TRTR.01090

Imazeki, J., 2014, 'Bring-your-own-device: Turning cell phones into forces for good', The Journal of Economic Education 45(3), 240-250. https://doi.org/10.1080/0022 0485.2014.917898

Inhelder, B. \& Piaget, J., 1958, The growth of logical thinking from childhood to adolescence: An essay on the construction of formal operational structures, Basic Books, Inc, New York.

Jones, T. \& Cuthrell, K., 2011, 'YouTube: Educational potentials and pitfalls', Computer in the Schools 28(1), 75-85. https://doi.org/10.1080/07380569.2011.553149

Johnson, R.B. \& Christensen, L.B., 2014, Educational research: Quantitative, qualitative and mixed approaches, 5th edn., Sage, Los Angeles, CA.

Kassing, G. \& Jay, D.M., 2003, Dance teaching methods and curriculum design, Human Kinetics, Champaign, IL.

Kawulich, B.B., 2005, 'Participant observation as a data collection method', Forum Qualitative Social Research 6(2), Art. 43, viewed 2 September 2015, from http:// nbn-resolving.de/urn:nbn:de:0114-fqs0502430
Kirk, C. \& Pitches, J., 2013, 'Digital reflection: Using digital technologies to enhance and embed creative processes', Technology, Pedagogy and Education 22(2), 213and embed creative processes', Technology, Pedagogy
230. https://doi.org/10.1080/1475939X.2013.768390

Klopfer, E., Osterweil, S., Groff J. \& Haas, J., 2009, Using the technology of today in the classroom of today: The instructionalpower of digital games, social networking simulations and how teachers can leverage them. The Education Arcade, Cambridge, MA.

Kucirkova, N., Messer, D., Critten, V. \& Harwood, J., 2014, 'Story-making on the iPad when children have complex needs: Two case studies', Communication Disorders Quarterly 36(1), 44-54. https://doi.org/10.1177/1525740114525226

Latham, D. \& Gross, M., 2014, Young adult resources today: Connecting teens with books, music, games, movies and more, Rowman \& Littlefield, Lanham, MD.

Leont'ev, A.N., 1997, 'On Vygotsky's creative development', in R.W. Rieber \& J. Wollock, (eds.), The collected works of L.S. Vygotsky. Volume 3: Problems of the theory and history of psychology, pp. 9-32, transl. R. Van Der Veer, Plenum Press, New York.

Lin, F.O., Esmahi, L. \& Poon, L., 2005, 'Integrating agents and web services into adaptive distributed learning environments', in F.O. Lin (ed.), Designing distributed learning environments with intelligent software agents, pp. 184-217, ISP, Hersey, NJ.

Marsh, J., 2005, 'Digikids: Young children, popular culture and media', in N. Yelland (ed.), Critical issues in early childhood education, pp.181-196, Open University Press, Buckingham.

McDonald, N.L. \& Fisher, D., 2006, Teaching literacy through the arts, Guilford Press, New York.

Merriam, S.B., 2002, Qualitative research in practice: Examples for discussion and analysis, Wiley, San Francisco, CA.

Merriam, S.B. \& Tisdell, E.J., 2015, Qualitative research: A guide to design and implementation, Jossey-Bass, San Francisco, CA.

Nompula, Y., 2012, 'An investigation of strategies for integrated learning experiences and instruction in the teaching of creative arts subjects', South African Journal of Education 32, 293-306. https://doi.org/10.15700/saje.v32n3a579

Owston, R.D. 1997, 'The World Wide Web: A technology to enhance teaching and learning?', Educational Researcher 26(2), 27-33. https://doi.org/10.2307/1176036

Pitler, H., Hubbell, E., Kuhn, M. \& Malenoski, K., 2007, Using technology with classroom instruction that works, ASCD, Alexandria, VA.

Republic of South Africa, 1996, 'The South African Schools Act, No. 84 of 1996', Government Printers, Pretoria.

Sauls, M.M., 2016, 'A study of the integration of technology in the school arts classroom', unpublished master's thesis, Nelson Mandela Metropolitan University, Port Elizabeth.

Scheffler, F. \& Logan, J., 1999, 'Computer technology in schools: What teachers should know and be able to do', Journal of Research on Computing in Education 31 know and be able to do', Journal of Research on Computing
305-325. https://doi.org/10.1080/08886504.1999.10782257

Scherer, M. \& Cator, K., 2011,'Transforming education with technology', Educational Leadership 68(5), 17-21.

Shulman, L.S. 1987, 'Knowledge and teaching: Foundations of the new reform', Harvard Educational Review 57(1), 1-22. https://doi.org/10.17763/haer.57.1.j4 $63 w 79 r 56455411$

Siegel, M., 1995, 'More than words: The generative power of transmediation for learning', Canadian Journal of Education 20, 455-475. https://doi.org/10.2307/ 1495082

Twiner, A., Coffin, C., Littleton, K. \& Whitelock, D., 2010, 'Multimodality, orchestration and participation in the context of classroom use of the interactive whiteboard: A discussion', Technology, Pedagogy and Education 19(2), 211-223. https://doi. org/10.1080/1475939X.2010.491232

Vermeulen, D., 2009, 'Implementing music in an integrated arts curriculum for South African primary schools', unpublished doctoral thesis, University of Pretoria,

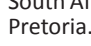

Vygotsky, L.S., 1978, Mind in society: The development of higher psychological processes, Harvard University Press, Cambridge, MA.

Walls, K.C., 2000, 'Technology for future music educators', Journal of Music Teacher Education 9(2), 14-21.

Ware, P.D., 2006, 'From sharing time to showtime! Valuing diverse venues for storytelling in technology-rich classrooms', Language Arts 84(1), 45-54.

Webster, F., 2006, 'The information society', in L.A. Lievrouw \& S. Livingstone (eds.), Handbook of new media: Social shaping and social consequences of ICT's, pp. 443-471, Sage, Thousand Oaks, CA.

White, J.W., 2009, 'Coffy, YouTube and Uncle Ben: The use of film and new media in the teaching of African American Studies at the University of Hawai' $i$ ', New Media in Higher Education 42(1/2), 47-53.

Wientjes, G., 2011, Creative genius in technology: Mentor principles from life stories of geniuses and visionaries of singularity, Lulu, Raleigh, NC. 